\title{
ANALISIS KEJADIAN STUNTING TERHADAP PERKEMBANGAN ANAK USIA 6-24 BULAN
}

\author{
Affi Zakiyya, Titin Widyaningsih, Rini Sulistyawati, Jehani Fajar Pangestu \\ Poltekkes Kemenkes Pontianak \\ email: affizakiyya@gmail.com
}

\begin{abstract}
Stunting is a condition of a person's height shorter than the height of other people in general (the same age). Stunting will affect physical performance and mental and intellectual functions will be disrupted. Children with stunting are left behind in several aspects of child development including: fine motor, gross motor, speech and language as well as socialization and independence. This study aims to analyze the relationship of stunting with the development of children aged 6 to 24 months in the working area of the Perumnas 2 Public Health Center in Pontianak, Kalimantan Barat. This type of re search is quantitative using a cross-sectional approach. The sample in this study consisted of 45 respondents in the are worked community health center Perumnas 2 pontianak. Based on the results of the study it can be concluded that partially the variables associated with stunting are social personal, fine motor, language and gross motor. After a logistic regression test It was found that stunting variables were simultaneously related to child development with a p-value of 0.0001
\end{abstract}

Keywords: stunting; child development; child gowth

\begin{abstract}
ABSTRAK
Stunting adalah kondisi di mana tinggi badan seseorang lebih pendek dibandingkan dengan tinggi badan orang lain yang seusia. Hal tersebut berdampak pada kinerja fisik dan fungsi mental serta intelektual pada penderitanya. Balita stunting sejak awal tertinggal dalam beberapa aspek perkembangan seperti; motorik halus, motorik kasar, bahasa serta personal sosial. Tujuan studi ini adalah menganalisis hubungan stunting dengan perkembangan anak usia 6-24 bulan di wilayah kerja Puskesmas Perumnas 2 Pontianak, Kalimantan Barat. Desain penelitian ini adalah kuantitatif menggunakan pendekatan potong lintang. Sampel dalam penelitian terdiri dari 45 responden di wilayah kerja Puskesmas Perumnas 2 Kota Pontianak menggunakan total sampling pada teknik pengambilan sampel. Hasil penelitian disimpulkan bahwa secara parsial variabel yang berhubungan dengan stunting adalah personal sosial, motorik halus, bahasa dan motorik kasar. Hasil analisis menggunakan uji regresi logistic ditemukan bahwa secara bersamaan variabel stunting berhubungan terhadap perkembangan anak dengan nilai $p$-value 0,0001 .
\end{abstract}

Kata Kunci: stunting; perkembangan anak; pertumbuhan anak 


\section{Pendahuluan}

Masa anak-anak merupakan masa di mana tumbuh dan berkembang paling pesat baik fisik, sosial maupun emosional (Wati \& Maharani, 2018). Masa anak-anak berisiko terjadinya stunting, dikarenakan berbagai faktor yang dapat menyebabkan stunting. Menurut Gibney (2008 dalam Panteleon; Hadi; Gamayanti, 2015) mengemukakan bahwa stunting (tubuh pendek) merupakan kondisi tubuh yang sangat pendek sampai melampaui defisit 2 Standar Deviasi (SD) di bawah median panjang atau tinggi badan dari populasi. Kondisi ini menggambarkan bahwa keadaan gizi yang kurang dan berjalan lama sehingga membutuhkan waktu yang lama untuk anak berkembang sampai kondisi yang ideal.

Kemenkes RI (2010), mengistilahkan pendek (stunting) adalah istilah gabungan pendek dan sangat pendek. Anak dengan stunting terbukti memiliki tingkat kematian lebih tinggi dari penyebab penyakit lainnya. Hal tersebut dijelaskan bahwa stunting mempengaruhi kinerja fisik dan fungsi mental dan intelektual. Selain itu juga terjadi gangguan fungsi kekebalan sehingga meningkatkan risiko kematian (Fitri, 2012).

Global Nutrition Report mendapatkan bahwa $22,2 \%$ balita didunia mengalami stunting pada tahun 2018 (Global Nutrition Report, 2018). Lebih dari setengah balita stunting di Asia sebanyak 55\% (Buletin Stunting, 2018). Tingginya prevalensi stunting dapat disebabkan oleh berbagai faktor, baik faktor secara langsung, yaitu asupan makanan dan status infeksi, maupun faktor tidak langsung seperti ASI eksklusif, pola asuh, lingkungan dan berbagai faktor lainnya (Bappenas, 2011). Faktor lainya dapat dipengaruhi oleh berat badan saat lahir, tinggi badan ibu, konsumsi gizi seimbang, status ekonomi, jumlah anggota dalam rumah tangga serta sumber air minum (Oktarina, 2012).

Stunting pada balita terjadi akibat dampak dari defisiensi nutrien selama seribu hari pertama kehidupan. Anak dengan stunting sejak awal lebih tertinggal dalam aspek kognitif dan motorik halus yang merupakan penunjang paling penting dalam pembelajaran dan pendidikan anak di masa mendatang (Permatasari dan Sumarni, 2018). Untuk mendeteksi adanya penyimpangan perkembangan dapat dilakukan dengan Denver Denver Developmental Screening Test (DDST) yang digunaan untuk mengetahui adakah penyimpangan pada perkembangan anak. Screening ini dapat dilakukan oleh tenaga kesehatan maupun orangtua yang ingin mengetahui perkembangan anaknya (Asthiningsih dan Muflihatin, 2018).

Pelaksanaan skrining berkala secara rutin dan berkala dapat mendeteksi adanya penyimpangan perkembangan balita, dengan tujuan dapat ditangani sedini mungkin sehingga balita dapat tumbuh dan berkembang dengan optimal (Nurfuqoni, 2017). Beberapa aspek perkembangan balita yang dipantau antara lain; motorik kasar yang berkaitan dengan kemampuan anak melakukan pergerakan yang melibatkan otot-otot besar. Aspek kedua adalah motorik halus yang berhubungan dengan kemampuan gerakan melibatkan bagian tubuh tertentu yang dilakukan oleh otot-otot kecil namun memerlukan koordinasi yang cermat. Aspek berikutnya adalah kemampuan bahasa yang berhubungan dengan kemampuan memberikan respons serta aspek personal sosial yang berhubungan dengan kemampuan mandiri anak.

Bebera[a penelitian juga menunjukkan bahwa kejadian stunting berhubungan dengan perkembangan balita 3-5 tahun. Aspek perkembangan tersebut adalah keterlambatan perkembangan bahasa dan motorik halus. jenis kelamin secara statistik berkaitan dengan perkembangan motorik (Hizni, 2010; Panteleon, 2015; Maharani, 2018). Pada penelitian ini peneliti akan melihat dan menganalisis setiap aspek perkembangan anak meliputi perkembangan motorik kasar, motorik halus, bicara dan bahasa serta personal dan kemandirian menggunakan instrument DDST.

\section{Metode Penelitian}

Penelitian ini menggunakan desain potong lintang. Penelitian dilaksanakan di Wilayah Kerja Puskesmas Perumnas 2 Pontianak, Kalimantan Barat pada bulan 
Januari sampai dengan Mei 2020. Sampel pada penelitian ini adalah balita stunting usia 6-24 bulan yang berdomisili di wilayah Puskesmas Perumnas 2 Kota Pontianak sejumlah 45 balita. Teknik pengambilan sampel menggunakan total sampling.

Instrumen untuk mengukur stunting yaitu dengan pengukuran antropometri TB/ $U$ menggunakan mictrotoise dengan kategori "sangat pendek" jika (<- 3 SD Z-TB/U) dan kategori "pendek" (- 3 SD <- 2 SD Z-TB/U). Instrumen untuk mengukur personal sosial, motorik halus, bahasa serta motorik kasar yang diisi oleh ibu balita menggunakan DDST-II yang dapat diisi oleh ibu balita. Kategori penyimpangan abnormal jika didapatkan 2 atau lebih keterlambatan, dan kategori suspct jika didapatkan satu atau lebih keterlambatan dan atau banyak kewaspadaan.

Analisis data pada penelitian ini dilakukan menggunakan analisis univariat, analisis bivariat dan multivariat. Analisis bivariat dilakukan untuk mengetahui hubungan antara stunting dengan perkembangan anak. Uji penelitian ini menggunakan Uji Korelasi Kendall Tau untuk mencari hubungan antara variabel stunting dan variabel perkembangan yang berskala ordinal.

Analisis multivariat dilakukan terhadap variabel yang berhubungan untuk mengetahui variabel yang paling dominan/ berpengaruh. Uji statistik yang akan digunakan dalam analisis penelitian ini adalah Regresi Logistik.

\section{Hasil dan Pembahasan}

Hasil

Penelitian dilakukan pada balita stunting dengan usia 6-24 bulan di wilayah Puskesmas Perumnas 2 Pontianak Barat. Hasil penelitian didapatkan data distribusi responden berdasarkan , jenis kelamin anak, pendidikan dan status pekerjaan orang tua. Data tersebut tersaji dalam Tabel 1. Jenis kelamin anak didominasi oleh perempuan, pekerjaan orang tua kategori terbanyak adalah Ibu Rumah Tangga (IRT) dan status pendidikan orang tua responden menempuh pendidikan Sekolah Dasar (SD).
Tabel 1. Distribusi responden berdasarkan usia, jenis kelamin dan status pekerjaan di Puskesmas Perumnas 2 Kecamatan Pontianak Barat

\begin{tabular}{lcc}
\hline $\begin{array}{l}\text { Karakteristik } \\
\text { Responden }\end{array}$ & $\begin{array}{c}\text { Frekuensi } \\
(\mathrm{n})\end{array}$ & $\begin{array}{c}\text { Persentase } \\
(\%)\end{array}$ \\
\hline Jenis kelamin & & \\
Anak & & \\
- Laki-laki & 17 & 37,8 \\
- Perempuan & 28 & 62,2 \\
Status Pekerjaan & & \\
Orang Tua & & \\
- IRT & 30 & 66,7 \\
- Pegawai & 10 & 22,2 \\
- Swasta & 2 & 4,4 \\
- Wirausaha & 3 & 6,7 \\
Status & & \\
Pendidikan Orang & & \\
Tua & & \\
- SD & 15 & 33,3 \\
- SLTP & 9 & 20,0 \\
- SLTA & 12 & 26,7 \\
- PT & 9 & 20,0 \\
\hline
\end{tabular}

Tabel 2: Karakteristik responden berdasarkan Stunting di wilayah kerja Puskesmas Perumnas 2 Kota Pontianak

\begin{tabular}{lcc}
\hline \multicolumn{1}{c}{ Kategori } & Jumlah & $\begin{array}{c}\text { Persentase } \\
(\%)\end{array}$ \\
\hline $\begin{array}{l}\text { Stunting: } \\
\text { a. Sangat }\end{array}$ & 34 & 75,6 \\
$\quad \begin{array}{l}\text { Pendek } \\
\text { b. Pendek }\end{array}$ & 11 & 24,4 \\
\hline
\end{tabular}

Pada Tabel 2 berisi data karakteristik responden berdasarkan status stunting. Prosentase terbesar didapatkan responden sangat pendek sejumlah $75,6 \%$ sedangkan $24,4 \%$ responden kategori pendek.

Pada Tabel 3 berisi data distribusi responden berdasarkan perkembangan anak. Pada kategori personal sosial motorik halus, bahasa dan motorik kasar didapatkan hasil prosentasu terbesar masuk dalam kategori perkembangan anak normal . kemudian disusul dengan perkembangan abnormal pada peringkat kedua. Pada kasus suspect memiliki prosentase lebih kecil dibandingkan kategori abnormal. 
Tabel 3: Distribusi Responden Berdasarkan Perkembangan Anak di wilayah kerja Puskesmas Perumnas 2 Kota Pontianak

\begin{tabular}{lcc}
\multicolumn{1}{c}{ Kategori } & Jumlah & Persentase (\%) \\
\hline Personal Sosial: & & \\
a. Normal & 22 & 48,9 \\
b. Abnormal & 17 & 37,8 \\
c. Suspect & 6 & 13,3 \\
Motorik Halus & & \\
a. Normal & 32 & 71,1 \\
b. Abnoral & 10 & 22,2 \\
c. Suspect & 3 & 6,7 \\
Bahasa & & \\
a. Normal & 27 & 60,0 \\
b. Abnormal & 10 & 22,2 \\
C. Suspect & 8 & 17,8 \\
Motorik Kasar & & \\
a. Normal & 25 & 55,6 \\
b. Abnormal & 14 & 31,1 \\
c. Suspect & 6 & 13,2 \\
\hline
\end{tabular}

Tabel 4: Uji Korelasi Kendall Tau

\begin{tabular}{lcccc}
\hline \multirow{2}{*}{ Variabel } & \multirow{2}{*}{ Sig } & \multirow{2}{*}{ OR } & \multicolumn{2}{c}{$95 \% \mathrm{Cl}$} \\
\cline { 4 - 5 } & & Lower & Upper \\
\hline $\begin{array}{l}\text { Personal } \\
\text { Sosial }\end{array}$ & 0,007 & 7,692 & 1,447 & 40,906 \\
\hline $\begin{array}{l}\text { Motorik } \\
\text { Halus }\end{array}$ & 0,011 & 6,300 & 1,479 & 26,831 \\
\hline Bahasa & 0,004 & 8,000 & 1,759 & 36,383 \\
\hline $\begin{array}{l}\text { Motorik } \\
\text { Kasar }\end{array}$ & 0,012 & 6,000 & 1,347 & 26,721 \\
\hline
\end{tabular}

Berdasarkan tabel 4 didapatkan uji korelasi Kendall Tau yang berhubungan dengan stunting adalah personal sosial, motorik halus, bahasa dan motorik kasar. Pada penelitian ini peneliti menggunakan nilai alpha 5\% maka dikatakan ada hubungan jika sig < 0,05.

Tabel 5: Uji Seleksi Multivariat

\begin{tabular}{lcc}
\hline \multicolumn{1}{c}{ Variabel } & Sig & Keterangan \\
\hline $\begin{array}{l}\text { Personal } \\
\text { Sosial }\end{array}$ & 0,007 & Kandidat \\
\hline $\begin{array}{l}\text { Motorik } \\
\text { Halus }\end{array}$ & 0,011 & Kandidat \\
\hline Bahasa & 0,004 & Kandidat \\
\hline $\begin{array}{l}\text { Motorik } \\
\text { Kasar }\end{array}$ & 0,012 & Kandidat \\
\hline
\end{tabular}

Berdasarkan tabel 5 didapatkan data hasil hitungan regresi logistik sederhana yaitu yang menjadi kendidat untuk sebagai uji analisis multivariat yaitu variabel personal sosial, motorik halus, bahasa dan motorik kasar dikarenakan nilai $p$-value $<0,25$.

Tabel 6: Uji Regresi Logistik Berganda

\begin{tabular}{lccccc}
\hline \multirow{2}{*}{ Variabel } & \multirow{2}{*}{ B } & \multirow{2}{*}{ Sig } & \multirow{2}{*}{ OR } & \multicolumn{2}{c}{$95 \% \mathrm{Cl}$} \\
\cline { 5 - 6 } & & & & Lower & Upper \\
\hline $\begin{array}{l}\text { Personal } \\
\text { Sosial }\end{array}$ & 3,4 & 0,02 & 31,4 & 1,55 & 636,8 \\
\hline $\begin{array}{l}\text { Motorik } \\
\text { Halus }\end{array}$ & 1,7 & 0,16 & 5,6 & 0,48 & 65,8 \\
\hline Bahasa & 3,2 & 0,02 & 25,3 & 25,30 & 409,5 \\
\hline $\begin{array}{l}\text { Motorik } \\
\text { Kasar }\end{array}$ & 2,7 & 0,03 & 15,5 & 1,16 & 207,3 \\
\hline $\begin{array}{l}\text { Hosmer }=0,692 \\
\text { R-Squere }=0,636\end{array}$ & & & & \\
Sig = 0,0001 & & & & \\
\hline
\end{tabular}

Berdasarkan tabel 6 didapatkan data hasil hitungan regresi logistik berganda yaitu ada hubungan secara signifikan antara antara peronal sosial, bahasa dan motirik kasar dengan stunting dengan $p$-value < 0,05. Hasil pengujian Hosmer and Lemeshow Test didapatkan hasil sig 0,692, artinya model cocok dikarena $>0,05$. Hasil uji deteminasi didapatkan nilai $R$-Squere sebesar 0,636 atau $63,6 \%$, artinya stunting mempengaruhi perkembangan anak sebesar $63,6 \%$, sisanya $36,4 \%$ dipengaruhi oleh faktor lain. Dilihat dari Uji Omnibus Tests of Model Coefficients didapatkan nilai sig sebesar $0,0001 \quad(<0,05)$, artinya secara bersamaan variabel stunting berhubungan dengan perkembangan anak.

Hubungan stunting dengan perkembangan personal sosial

Penelitian ini dilakukan dengan tujuan untuk mengetahui hubungan perkembangan personal sosial dengan stunting pada anak usia 6 sampai 24 bulan di wilayah kerja Puskesmas Perumnas 2 Kota Pontianak. Hasil penelitian menunjukkan bahwa sebagian besar perkembangan personal sosial anak normal sebanyak 48,9\%. Berdasarkan hasil hipotesa penelitian yang dapat dilihat dari tabel 5.4 didapatkan nilai $p$-value $=0,007$ artinya ada hubungan yang signifikan antara perkembangan personal sosial dengan stunting anak usia 6 sampai 24 bulan di wilayah kerja Puskesmas Perumnas 2 Kota Pontianak. 
Aspek personal sosial berkaitan dengan kemampuan mandiri, bersosialisasi dan berinterakti dengan lingkungan (Rumuy dkk, 2014). Pada penelitiannya disebutkan bahwa balita usia 15-23 bulan masih menangis ketika menunjukkan apa yang diinginkannya, pada usia 24-35 bulan belum mampu melepaskan pakaian secara mandiri dan sebagain besar masih menumpahkan banyak nasi saat makan. Penyebab terjadinya gangguan personal sosial karena kebanyakan ibu masih membantu anak dalam melakukan tugas tersebut, sehingga balita sedikit mendapat kesempatan dalam berkembang dalam aspek kemandirian.

Perkembangan personal sosial anak berhubungan dengan stunting sesuai dengan penelitian yang dilakukan oleh Asmaranggani, dkk (2018) bahwa ada hubungan antara kejadian stunting dengan perkembangan personal sosial anak prasekolah. Dijelaskan oleh Rahmadi dkk (2015 bahwa anak dengan stunting lebih rentan terjadi masalah emosi, perilaku dan masalah dengan teman sebaya dibandingkan pada anak dengan perawakan normal pada seusianya. Gangguan emosi pada ana stunting diwujudkan dengan keluhan menyerupai penyakit fisik, timbulnya rasa cemas dan tidak percaya diri. Gangguan perilaku diwujudkan dengan kesulitan mematuhi perintah, mudah berbohong, dan mengambil barang yang bukan miliknya. Sedangkan pada masalah dengan teman sebaya adalah anak lebih memilih meyendiri serta tidak memiliki teman dekat. Kurangnya rasa percaya diri ini didapatkan dari ejekan oleh teman sebaya sehingga kemampuan personal sosial kurang dan mengakibatkan kesulitan menjalin pertemanan dengan usia sebauanya. Permasalahan tersebut mendorong anak bersikap agresif atau bersikap sebaliknya, memilih tertutup dan menghindari bersosialisasi dengan teman sebaya.

Kekurangan zat gizi pada masa balita mempengaruhi tumbuh kembang dan aktivitas fisik yang berdampak pada perkembangan otak yang melalui perilaku . pola asuh dan interaksi anak dengan lingkungannya (Hanani dan Syuaqy, 2916). Anak dengan kondisi malnutrisi cenderung diperlakukan seperti anak yang berusia lebih muda dari usia normalnya, hal tersebut dapat menghambat personal anak. Selain itu anak lebih rentan terkena infeksi, mudah sakit dan dapat mengakibatkan penurunan aktifitas dan eksplorasi terhadap lingkungan. Dampak jangka panjang tersebut adalah perkembangan personal dan sosial anak di lingkungannya menjadi terhambat.

Aspek personal sosial berhubungan dengan kemampuan mandiri, bersosialisasi dan interaksi dengan lingkungannya (Soetjiningsih, 2015). Syamsu (2011) menilai bahwa aspek perkembangan personal sosial merupakan pencapaian kematangan dalam hubungan sosial. Dijelaskan bahwa perkembangan sosial diartikan sebagai proses belajar menyesuaikan diri terhadap norma-norma kelompok, tradisi dan menjalin kerja sama dengan komunikasi.

Peneliti berpendapat bahwa anak yang dengan stunting dapat memberikan dampak pada perkembangan pesonal sosial. pada periode usia 6-24 bulan merupakan salah satu periode kritis terhadap perkembangan anak tersebut. Anak dengan status gizi yang kurang baik akan mempengaruhi perkembangan anak salah satunya adalah personal sosial. Proses perkembangan ini akan terhambat. Dilihat dari perkembangan anak usia ini, bayi/ anak sudah dapat mengenali dan merespon ketka nama dipanggil. Mereka merasa senang saat harus berinteraksi dengan orang lain. Beberapa bayi/ anak cenderung lebih memiliki jiwa sosial dibanding yang lainnya. Diantara mereka ada yang mudah tersenyum, ada yang terpaku pada pandangan wajah orang tanpa tersenyum. Bayi/ anak yang mengalami keterlambatan menunjukkan sedikit sekali kertertarikan terhadap orang lain.

Hubungan stunting dengan perkembangan motorik halus

Penelitian ini dilakukan dengan tujuan untuk mengetahui hubungan stunting perkembangan motorik halus pada anak usia 6 sampai 24 bulan di wilayah kerja Puskesmas Perumnas 2 Kota Pontianak. Hasil penelitian menunjukkan bahwa sebagian besar perkembangan motorik halus anak normal sebanyak $71,1 \%$. Berdasarkan hasil hipotesa penelitian yang 
dapat dilihat dari tabel 5.4 didapatkan nilai $p$-value $=0,011$ artinya ada hubungan yang signifikan antara stunting dengan perkembangan motorik halus anak usia 6 sampai 24 bulan di wilayah kerja Puskesmas Perumnas 2 Kota Pontianak.

Motorik halus merupakan aspek yang berkaitan dengan kemampuan anak dalam mengamati sesuatu, melakukan gerakan yang melibatkan bagian tubuh tertentu saja namun dengan koordinasi yang cermat (Rumuy, dkk, 2014). Kemampuan tersebut diantaranya adalah melempar, menggambar, dan mengambil benda kecil. Pengalaman anak dalam memainkan memiliki peran penting dalam meraih dan menggenggam $(63 \%$ balita usia $12-14$ bulan sulit menggenggam pensil dengan baik). Pantaleon (2015) dalam penelitiannya menyebutkan bahwa kejadian stunting berhubungan dengan perkembangan motorik anak. Gangguan keterlambatan ini ditandai dengan kematangan sel-sel syaraf yang lambat, gerakan motorik dan respon sosial serta kurangnya kecerdasan. Berbagai stimulasi pada awal kehidupan memiliki pengaruh pada pertumbuhan dan maturasi otak, diantaranya adalah mencium, mendengar, melihat, dan meraba yang diberikan oleh orang tua sedini mungkin.

Pentaleon (2015) juga menjelaskan bahwa perkembangan kemampuan motorik bayi membantunya dalam melakukan ekspolrasi dan mempraktikkan kemampuan yang baru. Hal tersebut dimungkinkan karena pencapaian keterampilan motorik pada tahun pertama mampu meningkatkan kemandirian, meningkatkan kemungkinan bayi dapat menjelajah lingkungannya lebih leluasa dan memulai berinteraksi dengan orang lain. Pada tahun berikutnya motorik anak lebih terampil dan aktif, anak tidak lagi diam di satu tempat namun juga mampu bergerak ke seluruh ruangan. Aktifitas motorik pada tahun kedua ini memiliki peran penting bagi perkembangan kompetensi anak. Dalam eksplorasinya, anak hanya perlu diberikan sedikit batasan kecuali untuk keamanannya.

Pada prinsip perkembangan dijelaskan bahwa apek perkembangan pada anak saling mempengaruhi satu sama lain ke arah hubungan yang positif, nutrisi yang baik menambah tingkat perkembangan motorik halus sebesar 0,42\% (Hanani dan Syuaqy, 2016). Dijelaskan juga pada penelitiannya bahwa secara bersamaan motorik kasar dan halus berkembang tergantung dari pengalaman khusus yang dialami oleh anak dengan lingkungannya. Dengan berkembangnya motorik tersebut akan memampukan motorik anak berkembang dengan lebih kompleks. Terjadinya gangguan salah satu aspek perkembangan pada anak stunting dapat mengakibatkan terhambatnya kemampuan motorik anak yang lebih kompleks.

Aspek perkembangan motorik halus diantaranya adalah menggenggam benda kecil / mainan, mengkancingkan baju, memegang pensil dan menulis, ataupun kegiatan apapun yang memerlukan keterampilan tangan (Soetjiningsih, 2015). Dijelaskan juga bahwa keterampilan motorik halus semakin berkembang pesat setelah anak berusia 36 bulan, dan umumnya keterampilan tangan pada usia tersebut lebih cepat dikuasai dibandingkan keterampilan kata. Syamsu (2011) juga berpendapat bahwa perkembangan pada aspek motorik halus dipengaruhi oleh kesempatan anak dalam berlatih menulis, menyusun balok dan menggunting.

Peneliti berpendapat bahwa anak yang dengan stunting dapat memberikan dampak pada perkembangannya khususnya kemampuan motorik halus. Periode usia 6-24 bulan yang merupakan periode kritis perkembangan anak harus diperhatikan kemampuan motorik halusnya. Perkembangan motorik halus merupakan pondasi bagi semua aktivitas yang akan dilakukan anak untuk menumbuhkan rasa percaya diri dan rasa keingintahuan yang tinggi. Anak dengan stunting terhambat perkembangan motorik halusnya sehingga terjadi keterlambatan dalam perkembangan aspek yang lain. Perlunya stimulasi perkembangan yang terarah dan terukur akan lebih cepat berkembang dibanding dengan anak yang tidak diberikan stimulasi.

Hubungan stunting dengan perkembangan Bahasa

Penelitian ini dilakukan dengan tujuan untuk mengetahui hubungan stunting perkembangan bahasa pada anak usia 6 
sampai 24 bulan di wilayah kerja Puskesmas Perumnas 2 Kota Pontianak. Hasil penelitian menunjukkan bahwa sebagian besar perkembangan bahasa anak normal sebanyak 60,0\%. Berdasarkan hasil hipotesa penelitian yang dapat dilihat dari tabel 5.4 didapatkan nilai $p$-value $=0,004$ artinya ada hubungan yang signifikan antara stunting dengan perkembangan bahasa anak usia 6 sampai 24 bulan di wilayah kerja Puskesmas Perumnas 2 Kota Pontianak.

Hasil penelitian ini sesuai dengan penelitian yang dilakukan Probosiswi (2017) yang menunjukkan bahwa stunting berkaitan dengan perkembangan domain seperti kognitif, bahasa dan motorik. Kondisi stunting dapat mempengaruhi perkembangan otak secara langsung serta pertumbuhan fisik, aspek perkembangan motorik serta aktifitas fisik. Untuk meningkatkan perkembangan otak anak dapat dilakukan dengan pola asuh yang baik.

Teori perkembangan kognitif oleh Piaget disebutkan bahwa anak usia di bawah lima tahun dikategorikan dalam tahap perkembangan praoperasional, kondisi ini anak belum siap terlibat dalam operasi atau manipulasi mental yang menyaratkan pemikiran logis. Pada tahap ini, karakteristik yang timbul adalah perluasan penggunaan pemikiran simbolis atau kemampuan representasional seperti memahami identitas, sebab akibat, memiliki kemampuan mengklasifikasi, memahami angka serta perkembangan basa juga meningkat. Mulai usia 24 bulan anak memiliki perbendaharaan sebanyak 500 kata dan meningkat pada usia 36 bulan menjadi 900-1000 kata. Perkembangan bahasa meningkat pesat karena anak memiliki suatu sistematika dalam otak yang dikenal dengan istilah "mapping" (Hanani \& Syauqy, 2016).

Rumuy dkk (2014) dalam penelitiannya menyebutkan bahwa balita usia 12-14 bulan belum mampu meniru 2-3 kata sebanyak $45,5 \%$. Aspek bahasa pada anak merupakan aspek yang berhubungan dengan kemampuannya dalam memberikan respon terhadap suara, mengikuti perinta dan berbicara dengan spontan Penilaian pada aspek ini adalah anak mampu mengatakan dua suku kata yang sama seperti memanggil "mama" dan "papa' ketika melihat orangtuanya, mampu menunjuk bagian tubuh, mengambil mainan dan mengangkat piring jika mendapatkan perintah dengan benar.

Menurut Ikatan Dokter Anak Indonesia (IDAI) aspek perkembangan bahasa mencakup sarana komunikasi dengan menyimbolkan pikiran dan perasaan yang disampaikan maknanya kepada orang lain. Simbol tersebut bisa dengan tulisan, berbicara, ekspresi muka maupun insyarat antomim (Soetjiningsih, 2015). Seorang anak yang mengalami keterlambatan perkembangan umum dapat diketahui dengan laporan/data atau keluhan orang tua dalam pemeriksaan deteksi dini /skrining perkembangan anak. Skrining perkembangan sangat penting dilakukan dan harus dengan menggunakan instrumen yang tepat.

Peneliti berpendapat bahwa anak yang dengan stunting dapat memberikan dampak pada perkembangan bahasa. Pada usia 6-24 bulan merupakan salah satu periode kritis terhadap perkembangan bahasa pada anak. Kemampuan yang diperoleh dalam berbahasa pada anak merupakan aktivitas yang kompleks. Ketidakmampuan berbahasa pada anak dimungkinkan karena orang tua tidak menyadari bagaimana cara mengajarkan berbahasa kepada anaknya. Masalah aspek perkembangan bahasa berkaitan dengan perkembangan pikiran anak yang dapat dilihat dalam kehidupannya seperti anak sedang menangis, merengek, bertanya dan sebagainya. Komunikasi tersebut merupakan wujud ungkapan bahwa anak memiliki keinginan melalui pikirannya dan disampaikan dengan cara tersebut. Oleh karena itu, stimulasi yang baik perlu diberikan kepada anak untuk meningkatkan perkembangan bahasa anak dikarenakan jika kemampuan keluarga dalam menyediakan fasilitas bermain, menyediakan nutrisi tidak memadai akan menyebabkan otak anak kurang mendapatkan stimulasi.

Hubungan stunting dengan perkembangan motorik kasar

Penelitian ini dilakukan dengan tujuan untuk mengetahui hubungan stunting perkembangan motorik kasar pada anak 
usia 6 sampai 24 bulan di wilayah kerja Puskesmas Perumnas 2 Kota Pontianak. Hasil penelitian menunjukkan bahwa sebagian besar perkembangan motorik kasar anak normal sebanyak 55,6\%. Berdasarkan hasil hipotesa penelitian yang dapat dilihat dari tabel 5.4 didapatkan nilai $p$-value $=0,012$ artinya ada hubungan yang signifikan antara stunting dengan perkembangan motorik kasr anak usia 6 sampai 24 bulan di wilayah kerja Puskesmas Perumnas 2 Kota Pontianak.

Hasil penelitian ini sesuai dengan beberapa penelitian sebelumnya dianaranya adala Auliana dkk (2020) dalam penelitiannya menemukan bahwa ada hubungan yang signifikan antara stunting dengan perkembangan motorik kasar. Dijelaskan bahwa anak dengan stunting meningkatkan risiko empat kali lebih besar mengalami keterlambatan pada aspek motorik pada anak. Gangguan tersebut ditandai dengan kemampuan mekanik yang rendah dari otot tricepsurae yang menyebabkan keterlambatan kematangan fungsi otot. Hal tesebut dikarenakan terlambatnya kematangan sel-sel saraf, gerakn motorik, kurangnya stimulasi pada lingkungan sekitar dan kurangnya kecerdasan pada anak.

Aspek motorik kasar merupakan aspek yang berhubungan dengan pergerakan dan sikap tubuh. Rumuy dkk (2014) pada penelitiannya menyimpulkan balita sebanyak $80 \%$ mampu duduk, berjalan tanpa jatuh, naik tangga tanpa berpegangan, berdiri dan melompat dengan satu kaki. Beberapa gerakan kasar belum mampu dilakukan oleh balita sebanyak $45 \%$ usia $18-23$ bulan belum mampu membungkuk, mengambil mainan dan kembali berdiri tanpa jatuh. Gangguan keterlambatan perkembangan ditandai dengan lambatnya sel syaraf, gerakan motorik, kurangnya kecerdasan serta lambatnya respon sosial (Pantaleon, dkk, 2015).

Stimulasi pada anak melalui panca indra yang diberikan pada awal kehidupan memiliki pengaruh yang besar pada pertumbuhan dan maturasi otak (Pantaleon dkk, 2015). Kemampuan motorik anak membantu melakukan ekplorasi dan mempraktikkan kemampuan yang baru. $\mathrm{Hal}$ tersebut dimungkinkan karena keterampilan motorik pada tahun pertama kehidaupannya dapat meningkatkan personal sosial, dan bayi lebih dapat mengeksplorasi lingkungannya dengan lebih leluasa dan mulai berinteraksi dengan orang lain. Kemampuan anak lebih terampil dan aktif, tidak ingin diam di satu tempat dan bergerak pada setiap sudut ruangan meningkat pada tahun kedua.

Aspek perkembangan motorik kasar yaitu keterampilannya dalam menggunakan otot-otot besar (Soetjiningsih, 2015). Dijelaskan juga bahwa implikasi penting pada perkembangan motorik yaitu semakin bertambah usia maka kemandirian anak juga semakin bertambah. Anak mampu menjelajahi lingkungannya dan memprakartasi interaksi sosial dengan orang lain serta teman sebayanya. Perkembangan motorik kasar meliputi penggunaan otot-otot kasar seperti tangan, kaki dan badan yang diimplementasikan pada kegiatan duduk, berlari dan melompat (Syamsu, 2011).

Anak yang tidak diberikan atau kurang mendapatkan stimulasi perkembangan berdampak pada perkembangan motoriknya (Angraini, 2017). Hal tersebut dijelaskan bahwa jaringan otak anak yang mendapatkan stimulasi akan berkembang mencapai $80 \%$ pada usia kurang dari 48 bulan. Status gizi anak dikaitkan dengan perkembangan dan pertumbuhan, mental dan kemampuan berpikir anak (Suwandi dan Rafiony, 2018). Jaringan orak anak yang tumbuh dengan normal akan mencapai $80 \%$ dari berat otak orang dewasa sebelum menginjak usia 36 bulan, maka dari itu apabila pada masa tersebut mengalami gizi kurang sehingga mengalami kelainan fisik, mental dan perkembangan motorik anak.

Peneliti berpendapat bahwa anak dengan stunting memberikan dampak pada perkembangan motorik kasar. Anak stunting berdampak pada perkembangannnya yang terlambat dikarenakan pertumbuhannya yang bermasalah, maka sebab itu pertumbuhan dan perkembangan yang yang baik harus berjalan bersamaan. Anak stunting dengan riwayat tidak mendapatkan ASI serta asupan gizi seimbang selama kehamilan mengakibatkan kurang gizi pada anaknya saat lahir. Namun pada anak yang mengalami keterlambatan motorik kasar karena kurang gizi tersebut dapat diperbaiki 
karena pada masa ini anak dengan cepat mampu mengikuti arahan orang tua ataupun pengasuh. Pada balita yang mengalami stunting dapat diperbaiki dengan pemberian asupan gizi seimbang, karena pertumbuhan tinggi badan dapat dikejar hingga anak berusia $>18$ tahun.

Data hasil hitungan regresi logistik berganda yaitu secara parsial ada beberapa perkembangan anak yang berhubungan dengan stunting. Secara bersama-sama perkembangan anak yang terkait berhubungan dengan stunting sebesar $63,6 \%$, sisanya $36,4 \%$ dipengaruhi oleh faktor lain. Peneliti berpendapat bahwa dilihat dari hasil uji determinasi sebesar $63,4 \%$, artinya sangat besar hubungannya stunting dengan perkembangan anak meliputi perkembangan personal sosial, bahasa dan motorik kasar pada anak usia 6-24 bulan di wilayah kerja Puskesmas Perumnas 2 Kota Pontianak, masih ada $36,4 \%$ dipengaruhi oleh faktor lain. Setiawan dkk (2018), menyatakan bahwa ada faktor lain yang berhubungan dengan terjadinya perkembangan anak meliputi riwayat BBLR, status gizi, status ekonomi keluarga, pendidikan orang tua dan stimulasi orang tua.

Kondisi stunting pada anak berhubungan dengan beberapa perkembangan domain seperti kognitif, bahasa dan motorik. Stunting mempengaruhi pertumbuhan fisik dan perkembangan otak secara lansgung, mempengaruhi perkembangan motorik serta aktifitas fisik. (Probosiwi dkk., 2017). Pertumbuhan yang pendek dan perkembangan anak yang lambat pada anak stunting dikarenakan tidak terpenuhinya asupan gizi dan meningkatnya kesakitan dalam waktu yang lama (Hizni dkk, 2010). Probosowi dkk (2017) juga menyatakan bahwa bahwa HAZ score pada bayi usia 0-2 bulan memiliki korelasi yang kuat pada perkembangan motorik dan sosial emosi, yang disebabkan oleh kurang gizi saat lahir yang menyebabkan sel otak berkurang $15-20 \%$ sehingga berdampak pada perkembangan anak usia dini.

Berdasarkan tabel 5.6 Uji Regresi Logistik Berganda didapatkan bawah aspek perkembangan yang paling berhubungan dan dipengaruhi stunting adalah perkembangan bahasa. Hanum dan
Khomsan (2012) menyatakan bahwa tingkat kerumitan kalimat yang diucapkan anak meningkat seiring dengan bertambahnya umur antara 36-60 bulan. Anak dengan stunting tidak mempu mengenal alfabet dengan baik dan mengurut cerita bergambar seri $(41 \%)$ pada umur $41-52$ bulan dibandingkan anak dengan gizi normal cukup. Kemampuan menirukan urutan kata pada anak stunting sebesar $90 \%$ dan mengikuti perintah sederhana sebanyak $40 \%$ dibandingkan dengan balita normal sebanyak $83,3 \%$.

Anak setelah melewati fase bayi, perkembangan bahasa berlangsung sangat cepat (Wyethnutrition (2017). Secara umum perkembangan bahasa anak dibagi menjadi dua tahapan yaitu; 1) Tahapan pralnguistik yang berlangsung pada gase bayi. Pada fase ini cara komunikasi dengan menangis, menjerit, dan tertawa; 2) Tahap linguistik, merupakan fase belajar berbicara. Anak mampu mengucapkan kata-kata dengan baik dan merangkainya dalam satu kalimat. Pada anak stunting berdampak pada perkembangan bahasa. Diperkuat oleh penelitian yang dilakukan oleh Ayuni (2015) bahwa faktor yang mempengaruhi perkembangan antara lain: 1) umur anak; semakin matang pertumbuhan fisik seiring bertambah usia, serta pengalamannya dan kebutuhannya juga meningkat. 2) kondsi lingkungan, dapat memberi andil dalam kemampuan anak berbahasa. Lingkungan pedesaan akan berbeda dengan kemampuan bahasa di perkotaan, sama halnya dengan perkembangan bahasanya pada daerah terpencil, daerah pantai maupun kelompok sosial yang lain; 3) Kecerdasan anak, kemampuannya dalam meniru lingkungan seperti suara, gerakan, ataupun tanda-tanda maka seorang anak memerlukan kemampuan motorik yang sangat baik. Kemampuan motorik anak berkolerasi positif dengan kemampuan interlektualnya. Ketepatan anak dalam meniru, memproduksi pembendaharaan kata yang diingat, serta kemampuan memahami pernyataan orang lain; dan 4) sosial ekonomi keluarga: kondisi ini mempengaruhi kemampuan sebuah keluarga untuk menyediakan situasi yang mendukung pertumbuhan dan perkembangan anak dan anggota keluarga lainnya. 
Keterbatasan penelitian ini adalah Pengumpulan data pada variabel pencapaiaan perkembangan anak meliputi personal sosial, motorik halus, bahasa dan motorik kasar dengan menggunakan test DDST yang dilakukan hanya satu kali. Seharusnya dilakukan pemeriksaan ulang 1-2 minggu kemudian untuk menghindari bias pemeriksaan.

\section{Kesimpulan}

Ada hubungan secara signifikan antara antara peronal sosial, bahasa dan motirik kasar dengan stunting dengan $p$-value < 0,05 . Hasil pengujian Hosmer and Lemeshow Test didapatkan hasil sig 0,692, artinya model cocok dikarena $>0,05$. Hasil uji deteminasi didapatkan nilai $R$-Squere sebesar 0,636 atau $63,6 \%$, artinya stunting mempengaruhi perkembangan anak sebesar $63,6 \%$, sisanya $36,4 \%$ dipengaruhi oleh faktor lain. Dilihat dari Uji Omnibus Tests of Model Coefficients didapatkan nilai sig sebesar 0,0001 $(<0,05)$, artinya secara bersamaan variabel stunting berhubungan dengan perkembangan anak.

\section{Ucapan Terima Kasih}

Ucapan terima kasih kepada Kepala Direktur Poltekkes Kemenkes Pontianak, Dinas Kesehatan Kota Pontianak, Kepala Puskemas Perumnas II Pontianak serta jajarannya.

\section{Daftar Pustaka}

Asthinngsih, NWW., dan Muflihatin SK. 2018. Deteksi Dini Perkembangan Balita dengan Metode DDST II di Posyandu Wilayah Kerja Puskesmas Juanda Samarinda. Jurnal Endurance. Vol. 3 No. 2 tahun 2018

Auliana, D., Susilowati, E., Susiloningtyas, I. 2020. Hubungan Stunting dengan Perkembangan Motorik Anak Usia 2-3 Tahun di Desa Temuroso Wilayah Puskesmas Guntur 1 Kabupaten Demak. Junal Link, 16 (1), 49-53.
Ayuni, Q. A. 2015. Faktor yang Mempengaruhi Perkembangan Bahasa pada Anak. Tersedia di https://www.kompasiana.com. Diakses pada tanggal 28 Mei 2020.

BAPPENAS, 2011. Rencana Aksi Nasional Pangan dan Gizi 2011-2015. http://www.4shered.com/Rencana Aksi

\begin{tabular}{lll}
\hline Nasional Pangan. & Diakses & 02 \\
\hline November 2019. & &
\end{tabular}

Dharma, K.K., 2011. Metodologi Penelitian Keperawatan; Panduan Melaksanakan dan Menerapkan Hasil Penelitian. Trans Info Media, Jakarta.

Dinkes Kalbar, 2016. Profl Kesehatan Provinsi Kalimantan Barat Tahun 2015. Pontianak: Pemerintah Provinsi Kalimantan Barat.

Dinkes Kota Pontianak, 2017. Pedoman Pelaksanaan; Stimulasi, Deteksi dan Intervensi Dini Tumbuh Kembang Anak. Seksi KIA dan Reproduksi Dinas Kesehatan Kota Pontianak.

Fitri, 2012. Berat Lahir Sebagai Faktor Dominan Terjadinya Stuntingpada Balita (12-59 bulan) di Sumatra (Analisis Data Riskesdas 2010). FKMUI, Depok.

Gibney MJ. Gizi Kesehatan Masyarakat. Jakarta: EGC; 2008.

Global Nutrition Report, 2018. The Burdenof Malnutrition. Global Nutrition Report.

Hanani, R., Syuaqy, A. 2016. Perbedaan Perkembangan Motorik Kasar, Motorik Halus, Bahasa dan Personal Sosial pada Anak Stunting dan Non Stunting. Journal of Nursing Nutrition College, 5 (4), 412-418.

Hizni, A., Julia, M., Gamayanti, I.L, 2010. Status Stunted dan Hubungannya dengan Perkembangan Anak Balita di Wilayah Pesisir Pantai Utara Kecamatan Lemahwungkuk Kota Cirebeon. Jurnal Gizi Klinik Indonesia. 6 (3): 131-137.

Kemenkes RI, 2010. Riset Kesehatan Dasar 2010. Jakarta: Badan Penelitian dan Pengembangan Kesehatan, Kementrian Kesehatan RI.

2016. Pedoman Pelaksanaan: Stimulasi, Deteksi dan Intervensi Dini 
Tumbuh Kembang Anak. Jakarta: Kementrian Kesehatan RI.

Nurfurqoni, F.A, 2017. Pengaruh Modul Skrining Tumbuh Kembang terhadap Efektivitas Skrining Tumbuh Kembang Balita Studi Eksperimen terhadap Kader di Puskesmas Merdeka dan Bogor Timur. Midwife Journal. 3 (2): 65-73.

Panteleon, M.G., Hadi, H., Gamayanti, I,L, 2015. Stunting Berhubungan dengan Perkembangan Motorik Anak di Kecamatan Sedayu, Bantul, Yogyakarta. Jurnal Gizi dan Dietetik Indonesia, 3 (1): 10-21.

Permatasari, D.F., Sumarni, S, 2018. Differencesof Born BodyLength, HistoryofInfectiousDiseases, and Development betweenStuntingand Non-StuntingToddlers. Jurnal Berkala Epidemiologi. 6 (2): 182-191.

Probosiwi, H., Huriyati, E., Ismali, D, 2017. Stuntingdan perkembangan anak usia 12-60 bulan di Kalasan. JournalofCommunityMedicineandPublic Health. 33 (11): 1141-1146.

Profil Puskesmas Perumnas 2, 2019.

Setiawan, E., Machmud, R., Masrul, 2018. Faktor-Faktor yang Berhubungan dengan Kejadian Stunting pada Anak Usia 24-59 Bulan di Wilayah Kerja Puskesmas Andalas Kecamatan Padang Timur Kota Padang Tahun 2018. Jurnal Kesehatan Andalas. 7 (2): 275-284.

Rahmadi, F.A., Hardaningsih, G., Pratiwi, R. 2015. Prevalensi dan jenis Masalah Emosional dan Perilaku pada anak dengan Perawakan Pendek di Kabupaten Brebes. Jurnal Gizi Indonesia, 3 (2).
Rumuy, M., Khomsan, A., Hernawati, N. 2014. Pengaruh Riwayat Pemberian ASI, MP-ASI dan Status Gizi terhadap Perkembangan Balita. Bogor Agricultural University.

Setiawan, E., Machmud, R., Masrul. 2018. Faktor-faktor yang Berhubungan dengan Kejadian Stunting pada Anak Usia 24-59 Bulan di Wilayah Kerja Puskesmas Anadalas Kecamatan Padang Timur Kota Padan Tahun 2018. Jurnal Kesehatan Andalas, 7 (2), 275-284.

Soetjiningsi. 2015. Buku Ajar Tumbuh Kembang Anak dan Permasalahannya. Jakarta: Sagung Seto.

Suwandi., Rafiony, A. 2018. Hubungan Status Gizi (TB/U) terhadap Perkembangan Motorik Kasar pada Anak Usia 1-3 Tahun di Wilayah Kerja Puskesmas Korpri kabupaten Kubu Raya. Pontianak Nutrition Journal (PNJ),01 (01), 19-22.

Syamsu, Y. 2011. Psikologi Perkembangan Anak \& Remaja. Bandung: PT Remaja Rosdakarya.

TNP2K, 2018. Strategi Percepatan Pencegahan Stunting 2018-2024. Jakarta: Sekretariat Wakil Presiden RI.

Wati, D.E., Maharani, E.A, 2018. Perkembangan Penggunaan KPSP (Kuesioner Pra Skrining Perkembangan) Sebagai Alat Deteksi Tumbuh Kembang Anak untuk Meningkatkan Kompetensi Guru Paud Aisyiah di Wilayah Boyolali Jawa Tengah. Sniemas UAD: 333-337.

Wyethnutrition. 2017. Kenali Tahapan Perkembangan Bahasa Anak Usia Dini. https://www.wyethnutrition.co.id. Diakses pada tanggal 28 Me 2020. 